\title{
The differing approach to
}

commercial litigation in the European Court of Justice
and the courts of England \& Wales I

by Sir Anthony Clarke MR

This two-part article is taken from a lecture given to the Society for Advanced Legal Studies on February 23, 2006.

\section{INTRODUCTION}

I must begin with a word of thanks and a word of apology. The thanks are due to David Gladwell, who of course runs the Court of Appeal (and thus all our lives). He is a member of the Friends of the Institute of Advanced Legal Studies and about six months ago asked me if I would address this august body. So here I am, although I am not sure if thanks is quite the right word. It is one thing to agree to give a talk and quite another to prepare it. Fortunately I have had the great help of John Sorabji in doing so, although he has sensibly gone on holiday rather than listen to me. Present or not, my thanks are due to him. The good bits are his, the errors are mine.

The word of apology is that the title to this lecture does not give any very clear picture of what it will contain. Its purpose is to highlight the differing approaches taken by the English courts on the one hand and the European Court of Justice ("the ECJ") on the other to the exercise of its jurisdiction in civil and commercial matters. In particular recent decisions in the ECJ have shown that its approach to anti-suit injunctions is markedly different from the approach adopted here, especially by the Commercial Court and the Admiralty Court. The cases are well known. They are of course Erich Gasser GmbH v MISAT Srl [2005] QB 1, Turner v Grovit [2005] 1 AC 101 and Owusu $\checkmark$ Jackson (t/a Villa Holidays Bal Inn Villas) [2005] QB 801. These decisions and the rationale that underlies them to my mind have important implications for the future.

Before turning to an analysis of them and their implications I shall first say a word about the traditional English approach to questions of jurisdiction and its exercise, then turn to review the background and rationale underlying the Brussels Convention regime and its aims in an attempt to put the latest case developments in context and to highlight the different approach taken here and in Europe.

\section{APPROACH OF THE ENGLISH COURTS}

I have spent much of my professional life both at the Bar and as a judge dealing with cases in which parties, usually defendants, have done their utmost to avoid having the dispute tried on the merits in England. Arguments of every kind have been deployed over the years to persuade courts that the interests of justice lie in the issues being determined elsewhere, although in very many cases the true position is that the defendant's real interest is to ensure (if at all possible) that the issues will in practice never be determined at all.

The English courts have drawn a distinction between due service of process, which is necessary to confer jurisdiction on the court and the exercise of that jurisdiction. Thus the court may decline to exercise its jurisdiction and grant a stay on a number of different bases, depending upon the circumstances.

As to jurisdiction, the English courts have traditionally accepted jurisdiction, at least in so far as actions in personam are concerned, on four bases: presence in the jurisdiction, consent, exercise of the discretionary power to assume jurisdiction over parties out of the jurisdiction under what was RSC Order 11 and is now CPR 6.20 and 6.21 and international convention.

As to presence, it is to be noted that it was traditionally presence and not domicile which founded jurisdiction. As 
to consent, many commercial parties have consented to the jurisdiction of the English courts. Such consent can of course be given in a number of ways. For example, litigants domiciled outside England may voluntarily submit to the court's jurisdiction by appointing an agent in England to accept service on their behalf: see Tharsis Sulphar Cov Société des Metaux (1889) 58 LJQB 435. In such cases where jurisdiction was established as of right, the court would only grant a stay of an action where the defendant could show that the proceedings were in some way vexatious of oppressive: see eg McHenry v Lewis (1882) 22 Ch D 397 at 408 and Lord Morris's excellent summary of the development of this line of authority in The Atlantic Star [1974] AC 436 at $455 \mathrm{ff}$.

It was objected that this led to plaintiffs looking for a forum which would be most favourable to them and to undesirable forum shopping. Lord Denning's answer to that suggestion is to be found in his judgment in The Atlantic Star [1973] QB 364 at 381-82:

"No one who comes to these courts asking for justice should come in vain. ... This right to come here is not confined to Englishmen. It extends to any friendly foreigner. He can seek the aid of our courts if he desires to do so. You may call this 'forum shopping' if you please, but if the forum is England, it is a good place to shop in, both for the quality of the goods and the speed of service."

That has a certain ring to it, perhaps particularly appealing to those practising commercial law in London. However, it did not last. Due mainly to the efforts of Lord Goff, who had, as counsel, argued for their introduction in The Atlantic Star, the doctrine of forum non conveniens as understood in Scots law were introduced into English law: see The Abidin Daver [1984] AC 398. As I am sure all present are fully aware, this doctrine seeks to ascertain which country is a dispute's "natural forum" and to resolve an application for a stay or ant-suit injunction accordingly: see Spiliada Maritime Corporation v Cansulex Ltd [1987] AC 460 per Lord Goff at 478 . Where one party has brought proceedings in England concerning, for instance, the performance of a contract in the United States or Hong Kong it will try to ascertain which is the most appropriate forum to decide that dispute.

Why did the English courts adopt the Scottish approach? The answer is I think clear. It is an expression of the fundamental principle of doing substantial justice to the parties in litigation. This was recognised by Lord Goff in Spiliada. He said at page 474:

"In cases where jurisdiction has been founded as of right, i.e. where in this country the defendant has been served with proceedings within the jurisdiction, the defendant may now apply to the court to exercise its discretion to stay the proceedings on the ground which is usually called forum non conveniens. That principle has for long been recognised in Scots law; but it has only been recognised comparatively recently in this country. In The Abidin Daver [1984] AC
398, 411, Lord Diplock stated that, on this point, English law and Scots law may now be regarded as indistinguishable. It is proper therefore to regard the classic statement of Lord Kinnear in Sim v Robinow (1892) 19 R. 665 as expressing the principle now applicable in both jurisdictions. He said, at $p 668$ :

'the plea can never be sustained unless the court is satisfied that there is some other tribunal, having competent jurisdiction, in which the case may be tried more suitably for the interests of all the parties and for the ends of justice." "'

It is perhaps an example of the application of the principle stated by Lord Mansfield CJ as long ago as 1768 in Alderson v Temple (1768) 4 Burr. 235, where he said:

"The most desirable object in all judicial determinations, especially in mercantile ones, (which ought to be determined upon natural justice, and not upon the niceties of law, ) is, to do substantial justice."

See also per Lord Diplock in Bremer Vulcan v South India Shipping Corporation [1981] AC at 977.

The English courts thus adopted an approach, rooted in the jurisprudence of a civil law jurisdiction, which sought to ensure that cases were tried in the most appropriate forum in which their dispute can be resolved. This is a pragmatic approach exercised on a case by case basis. However, as is of course well known, the framers of the Brussels Convention rejected it in favour of a simpler and more certain approach, to which I will return in a moment.

In cases where there is no exclusive jurisdiction clause and English jurisdiction is established as of right and the doctrine of forum conveniens apply, it is for the defendant to persuade the court that the interests of justice require a stay of proceedings in favour of proceedings elsewhere. In cases where there is no exclusive jurisdiction clause and the permission of the court is necessary in order to permit service of the proceedings out of the jurisdiction, the claimant must satisfy the court first that the case falls within one of the categories of case set out in CPR 6.20 and, secondly, that the English court is "the proper place in which to bring the claim": see CPR 6.21(1) and 2A. The burden is thus on the claimant and not on the defendant. This is consistent with the principles in Spiliada.

The position is somewhat different if there is an exclusive jurisdiction clause in an agreement between the parties. This is an area in which there is a stark difference between our approach and that of the ECJ. In this class of case (and indeed in the case where there is an exclusive arbitration clause) the English approach has traditionally been that, where the parties have agreed a particular jurisdiction or arbitration in a particular place, the court will refuse or grant a stay (or anti-suit injunction) in favour of litigation or arbitration in the agreed forum unless there are strong reasons for not doing so: see eg The El Amria [1981] 2 Lloyd's Rep 119 and many other cases. I have 
often wondered why the courts conferred on themselves a discretion to allow a party to proceed in breach of an agreed jurisdiction or arbitration clause in a contract. There are, after all, no other terms of a contract which the court can disapply by the exercise of a discretion. In all other types of case the courts would (at any rate in the old days) simply have said pacta sunt servanda. However, that is by the by.

Until dealt what may be a fatal blow in Gasser and Turner (at any rate in the European context), the English courts adopted a robust approach to applications for anti-suit injunctions. They were willing to grant injunctions to restrain proceedings by claimants in other proceedings in breach of English exclusive jurisdiction or arbitration clauses. There are now many examples of this. It is sufficient to refer to Continental Bank NA v Aekos Compania Naviera SA [1994] 1 WLR 588 and The Angelic Grace [1995] 1 Lloyd's Rep 87. In the first case the English court granted an anti-suit injunction restraining proceedings brought before a Greek court in breach of an exclusive jurisdiction clause. It considered the question whether the procedural rule set out in Article 21 of the Convention overrode Article 17. It held it did not. In doing so the Court of Appeal relied upon the principle that substantive law takes precedence over procedural law. That approach was identified as being embodied in Article 17, which gives precedence to the courts of the agreed jurisdiction and thus enunciates the principle of party autonomy: see [1994] 1 WLR at 598. Thus parties should be held to their bargains so far as jurisdiction agreements are concerned, just as they should be held to other parts of their agreements.

The Court of Appeal took the view that to take any other view would lead to what were described as "ludicrous" consequences. The consequences which the court had in mind no doubt included a device that we all now know by the name of the Italian Torpedo, to which I will return in a moment. It is the device whereby, for purely tactical purposes, a litigant deliberately rushes to institute proceedings (perhaps for a declaration of non-liability) in a forum other than the one which has exclusive jurisdiction under a contract. The forum chosen is usually one which is renowned for slow moving civil process, which offers a wide scope for procedural skirmishing. The tactical purpose is of course to cause undue delay, unnecessary costs and thereby pressurise the other party to settle at an unduly low level. Its purpose is clearly antipathetic to the achievement of justice.

In The Angelic Grace the court was not faced with the breach of an exclusive jurisdiction clause, but rather with the breach of an arbitration clause. The court concluded that there was nothing in principle to distinguish the two types of breach. It thus concluded that the BrusselsLugano regime did not preclude the court from granting an anti-suit injunction. Again the English court adopted an approach which gave greater importance to holding the parties to their bargain than to the operation of a formal procedural rule.
Perhaps the clearest and typically incisive and robust statement of this principle is to be found in the judgment of Millett LJ in The Angelic Grace. I quote it in detail because it is the high water mark of the English approach. He said at page 96 :

"In my judgment, the time has come to lay aside the ritual incantation that this is a jurisdiction which should only be exercised sparingly and with great caution. There have been many statements of great authority warning of the danger of giving an appearance of undue interference with the proceedings of a foreign Court. Such sensitivity to the feelings of a foreign Court has much to commend it where the injunction is sought on the ground of forum non conveniens or on the general ground that the foreign proceedings are vexatious or oppressive but where no breach of contract is involved. In the former case, great care may be needed to avoid casting doubt on the fairness or adequacy of the procedures of the foreign Court. In the latter case, the question whether proceedings are vexatious or oppressive is primarily a matter for the Court before which they are pending. But in my judgment there is no good reason for diffidence in granting an injunction to restrain foreign proceedings on the clear and simple ground that the defendant has promised not to bring them.

The Courts in countries like Italy, which is a party to the Brussels and Lugano Conventions as well as the New York Convention, are accustomed to the concept that they may be under a duty to decline jurisdiction in a particular case because of the existence of an exclusive jurisdiction or arbitration clause. I cannot accept the proposition that any Court would be offended by the grant of an injunction to restrain a party from invoking a jurisdiction which he had promised not to invoke and which it was its own duty to decline.

We should, it was submitted, be careful not to usurp the function of the Italian Court except as a last resort, by which was meant, presumably, except in the event that the Italian Court mistakenly accepted jurisdiction, and possibly not even then. That submission involves the proposition that the defendant should be allowed, not only to break its contract by bringing proceedings in Italy, but to break it still further by opposing the plaintiff's application to the Italian Court to stay those proceedings, and all on the ground that it can safely be left to the Italian Court to grant the plaintiff's application. I find that proposition unattractive. It is also somewhat lacking in logic, for if an injunction is granted, it is not granted for fear that the foreign Court may wrongly assume jurisdiction despite the plaintiffs, but on the surer ground that the defendant promised not to put the plaintiff to the expense and trouble of applying to that Court at all. Moreover, if there should be any reluctance to grant an injunction out of sensitivity to the feelings of a foreign Court, far less offence is likely to be caused if an injunction is granted before that Court has assumed jurisdiction than 
afterwards, while to refrain from granting it at any stage would deprive the plaintiff of its contractual rights altogether.

In my judgment, where an injunction is sought to restrain a party from proceeding in a foreign Court in breach of an arbitration agreement governed by English law, the English Court need feel no diffidence in granting the injunction, provided that it is sought promptly and before the foreign proceedings are too far advanced. I see no difference in principle between an injunction to restrain proceedings in breach of an arbitration clause and one to restrain proceedings in breach of an exclusive jurisdiction clause as in Continental Bank NA v Aeakos Compania Naviera SA [1994] 1 WLR 588. The justification for the grant of the injunction in either case is that without it the plaintiff will be deprived of its contractual rights in a situation in which damages are manifestly an inadequate remedy. The jurisdiction is, of course, discretionary and is not exercised as a matter of course, but good reason needs to be shown why it should not be exercised in any given case.

As appears later, the contrast between the views of Millett LJ (and the other members of the court, namely Neill and Leggatt LJJ) on the one hand and those of the ECJ on the other is striking (to put it no higher). The approach taken by the English court in these cases places greatest weight on what commercial parties have agreed between themselves in arriving at the conclusion that it had the jurisdiction to impose anti-suit injunctions. Its interpretation of the regime in both cases rested on a case by case analysis of the merits of the particular case. The court in both cases was implicitly asking the question as to what justice, substantive justice, required it to do. Should it consistently with substantive law hold the parties to their bargain as to jurisdiction or arbitration? Or should it interpret the Convention so as to give one party a procedural advantage that would not only permit it to evade substantive law but permit it to evade substantive justice through use of a procedural device? The English courts took the view that substantive matters took precedence and that commercial parties who had reached a bargain should be held to that bargain. Procedural law should not be used to permit that bargain to be frustrated. Its commitment to affording precedence to the achievement of substantive justice informed its approach to interpretation of the Convention.

I will return in a moment to the inroads which have been made into those principles by Gasser and Turner.

The fourth class of case to which I referred earlier was jurisdiction under an international convention. The only such convention with which we are concerned this evening is the Brussels Convention on Jurisdiction 1965 as subsequently amended. The relevant rules are now contained in the Council Regulation (EC) Regulation 44/2001. I will call the whole system the Brussels-Lugano regime.

\section{THE BRUSSELS-LUGANO REGIME}

The regime was intended to provide those countries to which it applies with a single, uniform, jurisdictional system in the field of civil and commercial private international law. This aim was clearly set out in both the Brussels Convention's preamble and Rapporteur Jenard's report. It was intended to simplify, and render more expeditious, the procedure for the mutual recognition and enforcement of judgments of the courts of each contracting state in other contracting states under Article 220 (now Art 293) of the Treaty of Rome 1957. That was the Convention's aim. It was not however a freestanding one. Its aim furthered the implementation of a wider Community goal, which as Rapporteur Jenard records (see Jenard Report, preliminary remarks) was described in a note sent by the Commission of the European Economic Community to the six Member States requesting that they commence the negotiations that resulted in the Convention. The note stated that:

"a true internal market between the six States will be achieved only if adequate legal protection can be secured. The economic life of the Community may be subject to disturbances and difficulties unless it is possible, where necessary by judicial means, to ensure the recognition and enforcement of the various rights arising from the existence of a multiplicity of legal relationships. As jurisdiction in both civil and commercial matters is derived from the sovereignty of Member States, and since the effect of judicial acts is confined to each national territory, legal protection and, hence, legal certainty in the common market are essentially dependent on the adoption by the Member States of a satisfactory solution to the problem of recognition and enforcement of judgments."

The overarching aim of the Convention was thus to further the creation of a fully-functioning single internal market for the EEC pursuant to, for example, Articles 3 and 7 of the Treaty of Rome. This aim had two subsidiary, or what might better be described as, facilitative aspects. First it required an increase in legal certainty within the common market. As Jenard put it, the Convention sought to bring about "a genuine legal systematization ... (to) . . . ensure the greatest possible degree of legal certainty" (Jenard Report, chapter 4.2). This would in turn facilitate an increase in legal protection of those individuals and corporations domiciled within the common market.

These three aims have been stressed by the ECJ throughout the past 38 years: see for instance: Owusu Bank Ltd v Bracco [1994] ECR I-117. Equally they were stressed in Jenard and Möller's Report on the Lugano Convention: see paragraphs 4-5 and 8-11. They were again emphasised in the preamble to Regulation 44/2001 in the following terms:

"(1) The Community has set itself the objective of maintaining and developing an area of freedom, security and justice, in which the free movement of persons is ensured. In order to establish progressively such an area, the Community should 
adopt, amongst other things, the measures relating to judicial cooperation in civil matters which are necessary for the sound operation of the internal market.

(2) Certain differences between national rules governing jurisdiction and recognition of judgments hamper the sound operation of the internal market. Provisions to unify the rules of conflict of jurisdiction in civil and commercial matters and to simplify the formalities with a view to rapid and simple recognition and enforcement of judgments from Member States bound by this Regulation are essential."

Legal certainty was stressed in paragraphs 11 and 15 of the preamble.

The Brussels-Lugano regime's aims can thus be summarised as threefold: first, the creation of a single, straightforward and supranational code governing jurisdiction and the enforcement of judgments, which, secondly, increases legal certainty surrounding such matters in those nations which form part of its jurisdictional area and, thirdly, thereby assists the creation of a fully operative single internal market within those Member States.

The regime was to achieve these aims in two connected ways: first, by providing a directly effective system of law, or as in the United Kingdom's case an indirectly effective one in the form of the Civil Jurisdiction and Judgments Act 1982 ("the 1982 Act"), which overrode each Member State's own domestic law, except where recourse to such law was specifically provided for within the regime itself: see, for instance, Articles 1 (2), 4, 67 and 71 of the Regulation, the corresponding Articles of the Conventions and Sanicentral GmbH ${ }_{V}$ Collin [1979] ECR 3423; and secondly, by ensuring common, autonomous, interpretation of its terms: see Mulox $v$ Geels [1993] ECR I-4075 at 10-11. It was therefore not only a supranational jurisdictional regime, but one which operated according to supranational jurisprudence developed by the ECJ. It was inevitable that the ECJ would develop a European approach which would, at the very least differ from, and might well conflict with, the approach taken by national courts.

Its operation was likely (as has proved to be the case) to differ most starkly from the traditional English pragmatic approach because it operates along formalist lines. This is I think demonstrated by the three cases to which I referred earlier and to which I shall refer in a moment.

\section{The English approach to the Brussels-Lugano regime}

The regime became part of English law and is now set out in the Regulation, which has direct effect which is recognized in Civil Jurisdiction and Judgments Order 2001 (SI 2001/3929) and reflected in CPR 6.19. As a result, subject to certain restrictions, permission is not required in order to serve proceedings out of the jurisdiction in respect of a claim which the court has power to determine under the Regulation. There is no room for the doctrine of forum non conveniens, at any rate as between parties who are domiciled in a Member State or Member States, because the Regulation states which court has jurisdiction in each class of case. Moreover, it has detailed provisions as to which of one or more possible courts in different Member States has jurisdiction. Its essential philosophy is that the court first seised has jurisdiction and other do not: see Article 21 of the Convention (now Article 27 of the Regulation).

It is not necessary for me to set out the detailed provisions of the Regulation here for two reasons. The first is that you all know them by heart and the second is that, if I did, this lecture would never come to an end. It is sufficient to note that the basic principle that jurisdiction depends on domicile is contained in Article 2 of the Convention, now Article 2 of the Regulation. Article 16 of the Convention (now Article 17 of the Regulation) provides for exclusive jurisdiction in particular classes of case. Article 17 of the Convention (Article 23 of the Regulation) provides for the exclusive jurisdiction of the courts of a state in the case where the parties have included an exclusive jurisdiction clause in their contract. Article 21 (now Article 27) provides that, where proceedings involve the same cause of action, any court other than the court first seised must decline jurisdiction. Article 22 (now Article 28) provides that where actions are brought in the courts of different contracting states any court other than the court first seised may stay its proceedings.

It is right to say that the English courts initially took a narrow view of the regime's ambit. They did so by adopting an interpretative approach to the Brussels-Lugano regime which sought to keeps its ambit within bounds set by what they took to be its primary aim: the creation of a single market between the Member States. They took therefore an approach to the regime which sought to retain as broad an ambit of application for national law as was compatible with that aim.

This approach was clearly evidenced in the decision in the Court of Appeal in In re Harrods (Buenos Aires) Ltd [1992] Ch 72. In that case proceedings were brought in England in respect of the winding up of an English company. An issue arose as to whether Argentina was the more appropriate forum on the ground that the company carried out its business exclusively in Argentina. The Brussels Convention was (to use a Strasbourg expression) prima facie engaged as the company was the defendant in the action and was domiciled in England. However the Court of Appeal accepted an argument that the Convention did not apply because the question was whether the courts of a Member State or the courts of a non-Member State were the appropriate forum and the Convention only applied where the issue of jurisdiction was as between the courts of Member States.

In the Court of Appeal both Dillon and Nicholls LJJ concluded that the Brussels Convention was limited in its ambit to governing international relations between Member States amongst themselves, rather than governing 
Member States international relationships per se. They did so by identifying the Convention's purpose, in Jenard's words, as the creation of:

“. . . an autonomous system of international jurisdiction in relations between the Member States. . " (per Dillon LJ at 96.)

The single market was thus one that existed only as between Member States. That its scope was limited in this way flowed from its other aim, namely the creation of a common jurisdictional basis for the mutual recognition and enforcement of judgments between Member States. If that was the Convention's purpose under Article 220 of the Treaty of Rome, it was difficult to envisage how the Convention's jurisdictional rules could apply in litigation involving parties domiciled outside the Member States. Bingham LJ adopted a similar interpretative approach, although he did so by placing reliance on the aim of the Treaty and the Convention to create for the various Member States a single, jurisdictional unit between themselves alone and to do so by replacing prior bilateral agreements between several of the Member States: see page 101 et seq.

The rationale behind the Court of Appeal's decision was subject to a number of criticisms, of which the two most serious are noted in Cheshire \& North's Private International Law at page 264 as first, that it displayed a misunderstanding of the jurisdictional ambit of the Convention and, second, that it created uncertainty in the law. In Owusu the ECJ has held that the decision was wrong.

\section{The three decisions}

Before looking at the issues raised by the three decisions it is perhaps helpful to give an overview of them.

\section{Erich Gasser GmbH v MISAT Srl [2005] QB 1}

In Gasser proceedings were brought in both Italy and Austria arising out of an alleged breach of a commercial contract for the supply of children's clothing. The first set of proceedings was brought in April 2000 by MISAT before a court in Rome. In August 2000 Gasser commenced proceedings before a court in Feldkirch in Austria. Gasser argued that the Austrian court was the appropriate forum under the Convention because Austria was the place of performance of the contract within Article 5 (1) and because of a choice of jurisdiction clause in the contract, with the result that the Austrian court had jurisdiction under Article 17. MISAT argued that the Austrian court had no jurisdiction as it was domiciled in Italy and that Article 2 applied. It also contested the validity of the choice of jurisdiction clause and argued that the Roman court must determine that question as the court first seised. The Austrian court stayed the proceedings before it of its own motion in accordance with Article 21. Gasser appealed.

The Austrian appellate court referred two questions to the ECJ. It is the first of those which is of interest. It had two limbs: first, whether a court second seised could proceed to determine the case without waiting for the court first seised to determine jurisdiction where it, the court second seised, had exclusive jurisdiction under the contract; and secondly, if this were impermissible as a general rule, whether an exception to the effect of Article 21 could legitimately be made where the courts of the Member State first seised were subject to excessive procedural delay. The ECJ gave its judgment in December 2003 and answered both questions in the negative: the procedural rule embodied in Article 21 took precedence over Article 17 and no exceptions could be made to its operation on the basis of internal aspects of a Member State's procedural system: see the judgment at paragraph 46-47 and 70-73.

\section{Turner v Grovit [2005] 1 AC 101}

Shortly before Gasser was handed down substantially the same constitution of the ECJ heard Turner. The issue in the action was straightforward. Mr Turner, a solicitor, was employed by a group of companies as a legal adviser. During the course of his employment he was transferred to work in Madrid. He worked there for a very short period before he sought to terminate his employment. He then issued proceedings before an employment tribunal in England claiming unfair dismissal. Having dismissed an objection to the proceedings on the grounds of jurisdiction, the employment tribunal found in $\mathrm{Mr}$ Turner's favour. While those proceedings were continuing the defendants commenced proceedings against Mr Turner in Madrid alleging a breach of contract. Mr Turner applied for what is inelegantly known as an anti-suit injunction to restrain the defendants from proceeding with the Spanish action. An interim injunction was initially granted by the High Court in December 1998 but the judge refused to renew it in February 1999. Mr Turner appealed that refusal. The Court of Appeal allowed the appeal and reimposed the injunction.

Laws LJ gave the leading judgment. The Court of Appeal held that the English and Spanish proceedings were both concerned with the same subject matter, namely the termination of Mr Turner's contract, and that as the court first seised the English tribunal had exclusive jurisdiction under Article 21. More significantly perhaps the court held that the Spanish proceedings were brought merely to harass and intimidate Mr Turner. As Laws LJ put it:

$$
\begin{aligned}
& \text { ". . . it is to my mind plain beyond the possibility of } \\
& \text { argument that the Spanish proceedings were launched in bad } \\
& \text { faith in order to vex the plaintiff in his pursuit of the } \\
& \text { application before the Employment Tribunal here." }
\end{aligned}
$$

He said that the court's power to grant an anti-suit injunction to restrain such proceedings derived from its inherent jurisdiction to prevent the abuse of process and that that power was not inconsistent with the Brussels Convention. On the contrary he held that: 
“. . . the carefully constructed system of mutual recognition between jurisdictions established by the Brussels Convention is built on the premise that the courts of one State only will hear the case, and its judgment may be enforced, without further consideration of the merits, in any of the other contracting States. To my mind it follows that where a party in the courts of one State seeks to vex and oppress his opponent by process against him in another State, directed to issues which are being or could be litigated within the proceedings in the first State, the case is to all intents and purposes the same as one where, within this jurisdiction, one party oppresses his adversary by the issue and prosecution of multiple actions."

Unassisted by the decision of the ECJ, I would have formed the view that that reasoning was impeccable. The defendants appealed to the House of Lords, which was of the preliminary opinion that, where a second set of proceedings was commenced in bad faith, there was no inconsistency between the grant of such an injunction and the provisions of the Brussels Convention: see [2005] 1 AC at 106. However it referred the question to the ECJ. The ECJ in a short judgment disagreed with both the Court of Appeal and the preliminary view of the House of Lords. The ECJ held that such injunctions were impermissible because they were incompatible with the Convention and they were incompatible with the Convention because they ran counter to the doctrine of mutual trust between Member States, which underpinned the Convention.

Owusu v Jackson (t/a Villa Holidays Bal Inn Villas) [2005] QB 801

The third case raised the correct application of Article 2 of the Convention. Mr Owusu was domiciled in the United Kingdom. He hired a holiday villa in Jamaica from the first defendant, Mr Jackson. Whilst he was on holiday he suffered a serious injury, which resulted in him being left tetraplegic. The injury occurred while he was using a private beach owned and operated by the second defendant to which the terms of the holiday let gave him access. $\mathrm{Mr}$ Owusu brought a claim against Mr Jackson in England for damages for breach of contract. In addition he brought actions in tort against five Jamaican-based defendants. Four of the six defendants, including Mr Jackson, applied to the High Court for declaratory relief. The basis of their application was that the English court should decline jurisdiction or stay the action pursuant to the doctrine of forum non conveniens. They argued that Jamaica was the appropriate forum to hear the dispute because both the five Jamaican defendants and the relevant witnesses had closer links with Jamaica than with England and that the accident took place in Jamaica.

At first instance the judge refused to grant the order sought. He did so, following the ECJ's decision in Universal General Insurance Co (UGIC) v Group Josi Reinsurance Co SA [2001] QB 68 that jurisdiction under Article 2 of the
The judge held that, since the first defendant was domiciled in the UK, the court could not decline jurisdiction or stay the proceedings against him and that it followed that the appropriate forum for the proceedings against the other non-UK based defendants was England even though the Convention did not apply to them and Jamaica was in one sense the more convenient forum. It was more appropriate for the English court to have sole jurisdiction for all proceedings. Otherwise there was a risk that separate proceedings in the two countries would lead to inconsistent judgments on the same or similar facts and issues.

The defendants appealed to the Court of Appeal, which referred the following questions to the ECJ:

"(1) Is it inconsistent with the Brussels Convention... where a Claimant contends that jurisdiction is founded on Article 2, for a court of a contracting State to exercise a discretionary power, available under its national law, to decline to hear proceedings brought against a person domiciled in that State in favour of the courts of a nonContracting state:

(a) if the jurisdiction of no other Contracting State under the 1968 Convention is in issue;

(b) if the proceedings have no other connecting factors to any other Contracting State?

(2) If the answer to question 1 (a) or 1 (b) is yes, is it consistent in all circumstances or only in some and if so in which?"

Both the Advocate-General in his opinion and the ECJ in its judgment concluded that there was no scope for an application of the doctrine of forum non conveniens where a defendant was domiciled in a Member State. It made no difference to the exclusive applicability of Article 2 that the dispute centred on a non-member state and the acts or omissions of other defendants who were domiciled in that state.

This decision was perhaps predictable in the light of the court's reasoning in Turner. In paragraph 35 of his opinion in Turner Advocate-General Ruiz-Jarabo Colomer drew the following comparison:

"The effects of restraining orders are similar to those produced by application of the doctrine of forum non conveniens, whereby a decision may be made not to hear actions which have been brought in an inappropriate forum. Restraining injunctions, however much they are addressed to the parties and not to a judicial authority, presuppose some assessment of the appropriateness of bringing an action before a specific judicial authority. However, save in certain exceptional cases which are not relevant here, the Convention does not allow review of the jurisdiction of a court by a judicial authority of another contracting state: . . . "들

The Rt Hon Sir Anthony Clarke

Master of the Rolls 